\title{
Graves' ophthalmopathy: low-dose dexamethasone reduces retinoic acid receptor-alpha gene expression in orbital fibroblasts
}

1 Divisão de Endocrinologia, Departamento de Medicina Interna, Faculdade de Medicina de Botucatu, Universidade Estadual de São Paulo (Unesp), Botucatu, SP, Brasil 2 Instituto Federal de Educação,

Ciência e Tecnologia do Estado de São Paulo (IFSP) São Roque, SP, Brasil

${ }^{3}$ Departamento de Oftalmologia, Otorrinolaringologia e Cirurgia de Cabeça e Pescoço, Faculdade de Medicina de Botucatu Universidade Estadual de São Paulo (Unesp), Botucatu, SP, Brasil

Correspondence to:

Gláucia Maria Ferreira da Silva Mazeto Departamento de Medicina Interna, Universidade Estadual de São Paulo 18618-970 - Botucatu, SP, Brasil gmazeto@fmb.unesp.br

Received on Aug/31/2017 Accepted on Jan/23/2018

DOI: $10.20945 / 2359-3997000000044$
Sarah Santiloni Cury', Miriane Oliveira', Maria Teresa Síbio', Sueli Clara', Renata De Azevedo Melo Luvizotto', Sandro Conde², Edson Nacib Jorge ${ }^{3}$, Vania dos Santos Nunes' ', Célia Regina Nogueira', Gláucia Maria Ferreira da Silva Mazeto'

\begin{abstract}
Objective: Graves' ophthalmopathy (GO) is an autoimmune disease that leads to ocular proptosis caused by fat accumulation and inflammation, and the main treatment is corticosteroid therapy. Retinoid acid receptor-alpha (RAR $\alpha$ ) seems to be associated with inflammation and adipocyte differentiation. This study aimed to assess the effect of glucocorticoid treatment on orbital fibroblasts of GO patient treated or not with different glucocorticoid doses. Materials and methods: Orbital fibroblasts collected during orbital decompression of a female patient with moderately severe/severe $\mathrm{GO}$ were cultivated and treated with $10 \mathrm{nM}$ and $100 \mathrm{nM}$ dexamethasone (Dex). RAR $\alpha$ gene expression in the treated and untreated cells was then compared. Results: Fibroblast RAR $\alpha$ expression was not affected by $100 \mathrm{nM}$ Dex. On the other hand, $R A R \alpha$ expression was $24 \%$ lower in cells treated with $10 \mathrm{nM}$ Dex $(\mathrm{p}<0.05)$. Conclusions: Orbital fibroblasts from a GO patient expressed the RAR $\alpha$ gene, which was unaffected by higher, but decreased with lower doses of glucocorticoid. Arch Endocrinol Metab. 2018;62(3):366-9
\end{abstract}

\section{Keywords}

Receptors; retinoic acid; gene expression; Graves ophthalmopathy

\section{INTRODUCTION}

raves' ophthalmopathy (GO) is characterized by I expansion of the orbital tissue due to immunemediated inflammation and adipocyte proliferation secondary to orbital fibroblast (OF) differentiation (1). The main treatment for moderate to severe cases is corticosteroid therapy, which carries some risks $(2,3)$, while other therapeutic approaches have provided with limited results in a reasonable number of patients (4). Thus, new GO treatment options are being sought.

Retinoic acid (RA) is the biologically active form of vitamin A. It is widely used in clinical practice, especially in the form of isotretinoin for the treatment of acne (5). Nonetheless, studies indicate that RA may also play a role in adipogenesis $(6,7)$ and inflammatory/ autoimmune processes (8). The effects of RA depend on nuclear receptors from two families of nuclear transcription regulators: RA receptor (RAR) and retinoid X receptor (RXR) $(9,10)$. RAR, but not RXR, has affinity for all forms of RA (11). RAR $\alpha$ stands out as it is the most frequently expressed RAR in cells (12).

The OF of GO patients express RA receptors, including $\mathrm{RAR} \alpha$, and retinoids could inhibit adipocyte growth and differentiation, and induce apoptosis in these cells, consequently presenting therapeutic potential in GO $(13,14)$. However, the development of severe GO has been associated with the simultaneous use of RA, recombinant thyroidstimulating hormone (TSH), and radioactive iodine (15). Hence, the use of RA in GO may or may not have satisfactory results, depending on patient clinical condition, associated treatments, and RAR existence/ functionality/response. Other studies on the use of $\mathrm{RA}$ or the expression of its nuclear receptors in GO have not been found. 
We recently reported the case of a 62-year-old female patient with inactive, moderately severe to severe GO, not previously treated with glucocorticoid, whose fibroblasts expressed the peroxisome proliferatoractivated receptor-gamma (PPAR $\gamma)$ and estrogen receptor-alpha $(E R \alpha)$ genes. Interestingly, this gene expression responded to glucocorticoids in a doserelated manner $(16,17)$. Thus, the aim of this study was to evaluate the $R A R \alpha$ gene expression by cultured OF from GO patient, which were treated or not with different glucocorticoid doses.

\section{MATERIALS AND METHODS}

The present study, approved by the Research Ethics Committee of Botucatu Medical School under process number 4037-2011), assessed RAR $\alpha$ gene expression in cultured OF treated or not with $10 \mathrm{nM}$ or 100 $\mathrm{nM}$ dexamethasone (Dex). The cells were initially obtained during orbital decompression performed at the Clinics Hospital (HC) of the Botucatu Medical School (FMB) - Unesp, placed in a falcon tube containing the medium $199\left(\mathrm{LCG}^{\circledR}\right)$ and antibiotic, and transported to the experimental laboratory of medical clinic, where the cells were cultivated, as previously described $(16,17)$. Once the fibroblasts in the wells reached $80 \%$ confluence, they were treated with 10 $\mathrm{nM}$ or $100 \mathrm{nM}$ Dex in biological triplicates, and their $R A R \alpha$ gene expression was compared with that of untreated fibroblasts (control group, C) $(16,17)$. After treatment, the culture medium 199 was removed, and cells were collected from the plates with $400 \mu \mathrm{L}$ of TRIzol $^{\circledR}$ (Life Tech, USA) for RNA extraction, also perfomed with TRIzol ${ }^{\circledR}$. Sample integrity was verified by running them for 30 minutes in $1 \%$ agarose gel at a voltage of $80 \mathrm{mV}$. The RNA samples were then analyzed by spectrophotometry. Samples with 260:280 ratios below 1.6 were discarded because of protein contamination. Complementary deoxyribonucleic acid (cDNA) was synthesized from $1 \mu \mathrm{g}$ of RNA by reverse transcription using the High-capacity cDNA Reverse Transcription Kit (Applied Biosystems, CA, USA). In short, the following were added to the RNA sample: $2 \mu \mathrm{L}$ of $10 \mathrm{x}$ buffer, $0.8 \mu \mathrm{L}$ of $100 \mathrm{mM}$ dNTP mix, $2 \mu \mathrm{L}$ of random primer, $1 \mu \mathrm{L}$ of RNase inhibitor, 1 $\mu \mathrm{L}$ of reverse transcriptase, and $12.2 \mu \mathrm{L}$ of nucleasefree water. Samples were incubated at $25^{\circ} \mathrm{C}$ for 10 minutes, at $37^{\circ} \mathrm{C}$ for 120 minutes, at $85^{\circ} \mathrm{C}$ for 5 seconds, and maintained at $4^{\circ} \mathrm{C}$. Each cDNA sample was analyzed by TaqMan Assays (Life Technologies, USA) containing specific primers (ESRl: estrogen receptor alpha and cyclophilin: internal control) for the target RNAs. Each reaction used $10 \mu \mathrm{L}$ of TaqMan ${ }^{\circledR}$ Universal PCR Master Mix (Life Technologies, USA) and $3 \mu \mathrm{L}$ of the reverse transcription product. The final volume was adjusted to $20 \mu \mathrm{L}$ with nuclease-free water. Quantitative reverse transcription polymerase chain reaction (RT-qPCR) was performed as instructed by the Minimum Information for Publication of Quantitative Real-Time PCR Experiment (MIQE) (18). Samples were normalized by the internal control (cyclophilin), and gene expression was quantified by the 2-DDCT method (19). The control group was adjusted for comparison between groups $(16,17)$. All data were expressed as mean \pm standard deviation. Intragroup treatments were compared by two-factor analysis of variance (ANOVA) complemented by Tukey's multiple comparison test. The significance level was set at $5 \%$ $(\mathrm{p}<0.05)$.

\section{RESULTS}

Orbital fibroblasts expressed the $R A R \alpha$ gene. Gene expression in cells treated with $10 \mathrm{nM}$ Dex was $24 \%$ lower than the control group $(\mathrm{p}<0.05)$. However, gene expression in cells treated with $100 \mathrm{nM}$ Dex was not significantly different from controls or the $10 \mathrm{nM}$ Dex group (Figure 1).

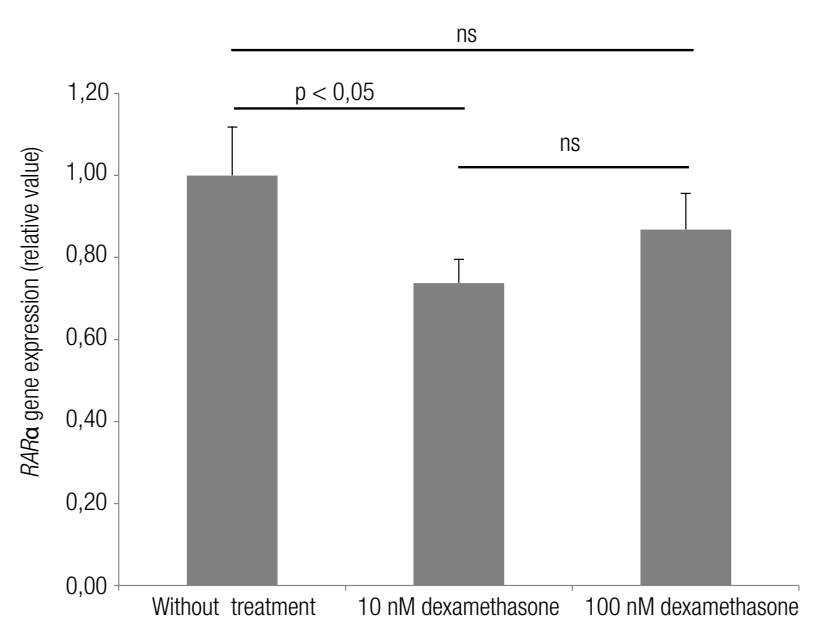

Figure 1. Effect of $10 \mathrm{nM}$ and $100 \mathrm{nM}$ dexamethasone on retinoic acid receptor alpha $(R A R \alpha)$ mRNA in orbital fibroblasts from a patient with Graves' ophthalmopathy. The experiment was performed in triplicate. Data were reported as mean and standard deviation. ANOVA was used in conjunction with Tukey's test $(p<0.05)$.

ns: not significant. 


\section{DISCUSSION}

This study confirmed that the OF of GO patients expressed the RAR $\alpha$ gene. Lower doses of glucocorticoid reduced $R A R \alpha$ gene expression while higher doses did not change it significantly.

RA plays an important role in adipogenesis. Low RA concentrations promote adipocyte differentiation (7), but supraphysiological concentrations inhibit it (6). These findings indicate the importance of studying RA receptors in disorders where adipocytes differentiate and proliferate as a pathophysiological mechanism. Normal human fibroblasts from the lungs and skin express $R A R \alpha$, and its expression is modulated in certain situations, such as types of cell growth conditions, and treatment with ascorbic acid, for example $(20,21)$. Likewise, the OF of patients with GO express $R A R \alpha$, which respond differently, depending on the concomitant medication used $(13,15)$.

An impact of RAR in GO physiopathology could be its role in adipogenesis. Wang and cols. found that mouse adipocytes treated with all-trans-retinoic acid (ATRA) had higher $R A R$ expression, $R A R \gamma$ more so than $R A R \alpha$, with consequent decrease of PPAR $\gamma$ expression (14). It is known that PPAR $\gamma$ plays a role in GO development, and recently, we reported that OF from a GO patient treated with small doses of corticosteroid had higher PPAR $\gamma$ gene expression. This could lead to higher differentiation of fibroblasts into adipocytes and speculation that higher glucocorticoid doses would better treat this disease (16).

Yet, in addition to adipogenesis, inflammation also has an important role in GO pathophysiology (1). Thus, vitamin A could act on immunity and inflammation. In autoimmune diseases, RA helps T-cell induction and gene regulation via RAR, which behaves as a transcription factor (8), making RAR essential for preventing and maintaining the tolerance to autoimmune/inflammatory diseases. In light of this, RA treatment could drive distinct pathogenesis evolution by its effects through RAR-modulated pathways in OF, mainly by changing cellular proliferation, differentiation, and apoptosis (13). Indeed, OF from GO patients treated with RA presented morphological alterations, and a decrease in cell growth/proliferation accompanied by the expression of RAR subtypes (13). Moreover, RAR $\alpha$ agonist inhibited $36 \%$ of the TGF- $\beta 1$ stimulatory effect on extracellular matrix remodeling and human Tenon fibroblast contractility (22).
Despite this, there is a lack of knowledge regarding the molecular mechanisms of RAR activation in GO. In addition, the OF from GO patients have a hyperresponsive phenotype and consist of several cell subsets, such as $\mathrm{Thyl}^{+} /$Thyl $^{-}$, fibrocytes/CD34+ (23). Perhaps RAR stimulation in different types of fibroblasts could result in different responses, aimed at adipogenesis or fibrogenesis. Our results show that different doses of glucocorticoid, the main treatment for moderate to severe cases of GO, can lead to a differential $R A R \alpha$ expression. This finding suggests that corticotherapy could alter the OF phenotype for $R A R$, and adds another variable to the pathophysiology of OG since it could result in a different response from these receptors to eventual stimuli.

To summarize, in the GO treatment, the appropriate RAR expression, modulated by glucocorticoid therapy, would help to reduce adipocyte proliferation and inflammation. As the smaller Dex dose reduced $R A R \alpha$ expression, and the higher dose did not affect it, as observed with PPAR (16), one could speculate that lower glucocorticoid doses would have lesser effects, both anti-inflammatory and in inhibiting adipocyte differentiation. Considering the eventual therapeutic role of retinoids in GO, and the dynamic and sensitive mechanism that modifies RAR $\alpha$ mRNA levels in fibroblasts, higher doses of glucocorticoids would be more appropriate if combined with RA.

This study has some limitations, such as using OF from a single patient and not investigating other RA receptors or their protein expression. However, to our knowledge, this was the first study assessing $R A R \alpha$ gene expression by the OF from a GO patient treated with different glucocorticoid doses, given that glucocorticoids are currently the main treatment for this ocular disorder.

In conclusion, the orbital fibroblasts from a GO patient expressed the $R A R \alpha$ gene, which was not affected by higher, but decreased with lower, glucocorticoid doses. Other studies with more patients are needed to confirm these results.

Acknowledgment: the authors are grateful to the Research Support Foundation of the State of Sao Paulo (Fapesp) for financial support (grant \#:03/03651-0 and 2011/18464-8).

Disclosure: no potential conflict of interest relevant to this article was reported. 


\section{REFERENCES}

1. Iyer S, Bahn R. Immunopathogenesis of Graves' ophthalmopathy: the role of theTSH receptor. Best Pract Res Clin Endocrinol Metab. 2012;26(3):281-9.

2. Bahn R. High-dose intravenous glucocorticoid therapy for Graves' ophthalmopathy: where are we now? Thyroid. 2012;22(1):1-2.

3. Philip R, Saran S, Gutch M, Agroyia P, Tyagi R, Gupta K. Pulse dexamethasone therapy versus pulse methylprednisolone therapy for treatment of Graves's ophthalmopathy. Indian J Endocrinol Metab. 2013;17(Suppl 1):S157-9.

4. Bartalena L, Baldeschi L, Boboridis K, Eckstein A, Kahaly GJ, Marcocci C, et al.; European Group on Graves' Orbitopathy (EUGOGO). The 2016 European Thyroid Association/European Group on Graves' Orbitopathy Guidelines for the Management of Graves' Orbitopathy. EurThyroid J. 2016;5(1):9-26.

5. Owen CE. Treating acne with high-dose isotretinoin. JAMA. 2014;311(20):2121-2.

6. Sato M, Hiragun A, Mitsui $H$. Preadipocytes possess cellular retinoid binding proteins and their differentiation is inhibited by retinoids. Biochem Biophys Res Commun. 1980;95(4):1839-45.

7. Safonova I, Darimont C, Amri EZ, Grimaldi P, Ailhaud G, Reichert $U$, et al. Retinoids are positive effectors of adipose cell differentiation. Mol Cell Endocrinol. 1994;104(2):201-11.

8. Kim $\mathrm{CH}$. Retinoic acid, immunity, and inflammation. Vitam Horm. 2011;86:83-101.

9. Evans RM. The steroid and thyroid hormone receptor superfamily. Science. 1988;240(4854):889-95.

10. Green S, Chambon P. Nuclear receptors enhance our understanding of transcription regulation. Trends Genet. 1988;4(11):309-14.

11. Mangelsdorf DJ, Ong ES, Dyck JA, Evans RM. Nuclear receptor that identifies a novel retinoic acid response pathway. Nature. 1990;345(6272):224-9.

12. Elder JT, Fisher GJ, Zhang QY, Eisen D, Krust A, Kastner P, et al. Retinoic acid receptor gene expression in human skin. $J$ Invest Dermatol. 1991;96(4):425-33.

13. Pasquali $D$, Bellastella $A$, Colantuoni $V$, Vassallo $P$, Bonavolontà $\mathrm{G}$, Rossi V, et al. All-trans retinoic acid- and N-(4-hydroxyphenil)- retinamide-induced growth arrest and apoptosis in orbital fibroblasts in Graves' disease. Metabolism. 2003;52(11):1387-92.

14. Wang $X$, Yang $P$, Liu J, Wu H, Yu W, Zhang T, et al. RAR $\gamma$-C-FosPPAR $\gamma 2$ signaling rather than ROS generation is critical for alltrans retinoic acid-inhibited adipocyte differentiation. Biochimie. 2014;106:121-30.

15. Berg G, Andersson T, Sjödell L, Jansson S, Nyström E. Development of severe thyroid-associated ophthalmopathy in a patient with disseminated thyroid cancer treated with recombinant human thyrotropin/radioiodine and retinoic acid. Thyroid. 2005;15(12):1389-94.

16. Cury SS, Oliveira M, Síbio MT, Clara S, Luvizotto RD, Conde S, et al. Graves ophthalmopathy: low-dose glucocorticoid increases peroxisome proliferator-activated receptor-gamma gene expression. Arq Bras Oftalmol. 2014;77(5):339-340.

17. Cury SS, Oliveira M, Síbio MT, Clara S, Luvizotto Rde A, Conde $S$, et al. Gene expression of estrogen receptor-alpha in orbital fibroblasts in Graves' ophthalmopathy. Arch Endocrinol Metab. 2015;59(3):273-6.

18. Bustin SA, Benes V, Garson JA, Hellemans J, Huggett J, Kubista $M$, et al. The MIQE guidelines: minimum information for publication of quantitative real-time PCR experiments. Clin Chem. 2009;55(4):611-22

19. Livak KJ, Schmittgen TD. Analysis of relative gene expression data using real-time quantitative PCR and the 2(-Delta Delta C(T)) Method. Methods. 2001;25(4):402-8.

20. Jaworski J, Klapperich CM. Fibroblast remodeling activity at twoand three-dimensional collagen-glycosaminoglycan interfaces. Biomaterials. 2006;27(23):4212-20.

21. Duarte $T L$, Cooke MS, Jones GD. Gene expression profiling reveals new protective roles for vitamin $C$ in human skin cells. Free Radic Biol Med. 2009;46(1):78-87.

22. Liu Y, Kimura K, Orita T, Suzuki K, Teranishi S, Mori T, Sonoda K. Inhibition by a retinoic acid receptor $\gamma$ agonist of extracellular matrix remodeling mediated by human Tenon fibroblasts. Mol Vis. $2015 ; 21: 1368-77$.

23. Dik WA, Virakul S, van Steensel L. Current perspectives on the role of orbital fibroblasts in the pathogenesis of Graves' ophthalmopathy. Exp Eye Res. 2016;142:83-91. 